\title{
Chemical weed control in winter wheat: Efficiency and economic return
}

\author{
Juhani Uoti and Tuomo Juvankoski \\ Kemira Oy, PL 330, 00101 Helsinki 10
}

\begin{abstract}
In field trials in Vihti during the years 1968-1978 the average yield increase in winter wheat obtained with chemical weed control was $439 \mathrm{~kg} / \mathrm{ha}$ with a yield level of $3704 \mathrm{~kg} / \mathrm{ha}$. The moisture content in percentages was $1.2 \%$ lower in the sprayed plots than in the unsprayed plots. The number and the dry weight of weeds was greatly reduced by the spraying. The producer price for the wheat being at present $1 \mathrm{mk} / \mathrm{kg}$, the value of the yield increase for the farmer is $439 \mathrm{mk} / \mathrm{ha}$, whereas the decrease of the moisture content saves in drying costs $36 \mathrm{mk} / \mathrm{ha}$. When the spraying costs estimated at $153 \mathrm{mk} / \mathrm{ha}$ have been deducted from these figures, the net return for the farmer is $322 \mathrm{mk} / \mathrm{ha}$.
\end{abstract}

\section{Introduction}

Chemical weed control in cereals is now a routine farm practice in Finland. According to statistics, $60-80 \%$ of the cereal growing area has been yearly treated with herbicides (Tirttanen and Blomovist 1978). It is obvious that even a greater proportion of the winter wheat area is sprayed, although it is impossible to check it from the sales statistics, since the same herbicides may be used for winter and spring cereals.

In winter wheat both autumn- and spring-germinating weed species may be found (ERviö 1978). A stand suffering from over-wintering problems is particularly confronted with a strong competition from the weeds. Mayweed (Matricaria inodora L.,) which is probably the most important weed species in winter wheat (MUKula 1963), is a strong competitor and a typical autumngerminating species.

The most common herbicides in winter wheat are 2,4-D, mecoprop and various mixtures of phenoxyacids and dicamba or bromoxynil and ioxynil.

The cost of these herbicides varies from $50 \mathrm{mk} / \mathrm{ha}$ to over $100 \mathrm{mk} / \mathrm{ha}$.

Studies showing the importance of weed control are generally limited to indicating the decrease of weeds and the increase of crop yield. BREITENSTEIN (1971) has also tried to estimate the effect of chemical weed control on the harvesting and drying costs, but actual trial results are not available. In the present study an attempt has been made to show the economic return of chemi- 
cal weed control in winter wheat taking into consideration the yield increase and the moisture decrease based on the material accumulated from the field trials conducted in southern Finland during the years 1968-78.

\section{Material and methods}

The trials were established in normal farm fields either at the Kotkaniemi experimental farm in Vihti, $50 \mathrm{~km}$ northwest of Helsinki, or at the local farms near Kotkaniemi. The trial site was selected in the spring just before spraying. A basis for the selection was an even crop stand and an equally even weed distribution. During the years 1968-69 there was only one trial per year, whereas in other years $2-4$ trials were estabished at different locations. In 1975 there were no trials due to a lack of suitable sites. Altogether there were 22 trials.

In the first years the plot size was $4 \times 20 \mathrm{~m}$, but later the plot size had to be cut down to $2.5 \times 10 \mathrm{~m}$ for practical reasons. There were four replicates in every trial.

The sprayings were done with a portable Azo-propan sprayer equipped with a 4 or $2.5 \mathrm{~m}$ boom and flat jet nozzles. The amount of water was $300 \mathrm{l} / \mathrm{ha}$. After four weeks from the spraying the weeds were counted by species from the area of $0.25 \mathrm{~m}^{2} / \mathrm{plot}$. At the time of harvesting the weeds were collected from the same area, and their dry weight was determined. The wheat crops were harvested to determine the grain yield.

The four compound mixture, Actril 4, was used as a herbicide. Its components are bromoxynil $38 \mathrm{~g} / \mathrm{l}$, ioxynil $57 \mathrm{~g} / 1,2,4-\mathrm{DP} 297 \mathrm{~g} / \mathrm{l}$ and MCPA 127 $\mathrm{g} / \mathrm{l}$. The rate per hectare was $5.5 \mathrm{l}$. In the years $1969-71$ a similar product, Actril 3, was used. It differed from Actril 4 only slightly; bromoxynil had been replaced with an addition of ioxynil up to $70 \mathrm{~g} / \mathrm{l}$. In 1978 a new formulation
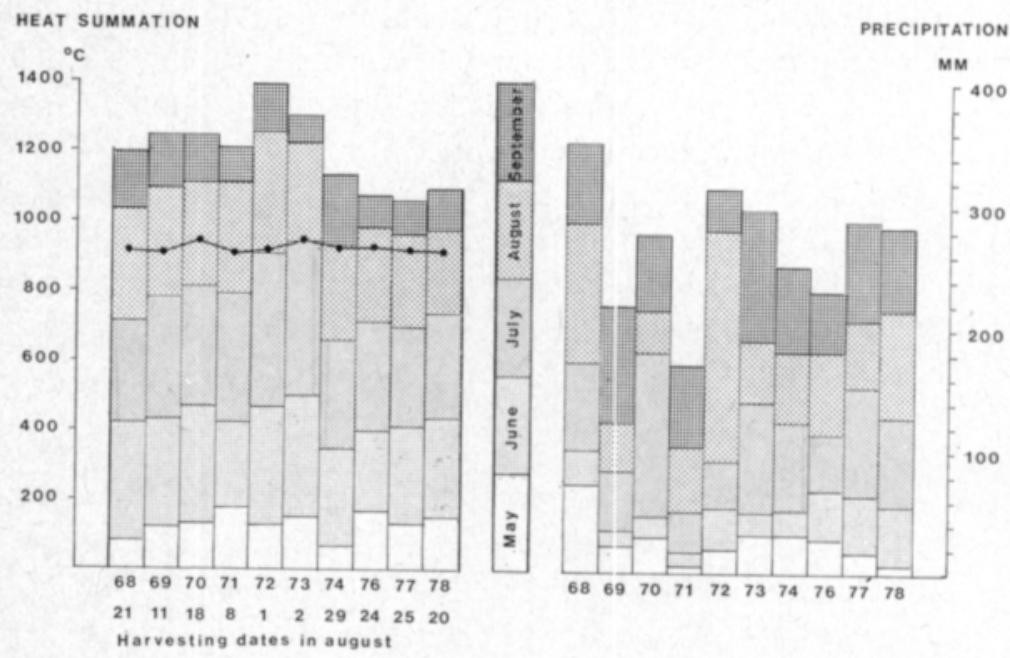

Fig. 1. Heat summation and precipitation in the summer months (May-September) in 1968-1978 at the Maasoja weather station. Harvesting dates also plotted to the keat summation diagram. 
based on reduced rates of active ingredients was used. This mixture, Actril S, was sprayed with $4 \mathrm{l} / \mathrm{ha}$, and its components were bromoxynil $25 \mathrm{~g} / \mathrm{l}$, ioxynil $40 \mathrm{~g} / 1,2,4-D P 200 \mathrm{~g} / 1$ and MCPA $250 \mathrm{~g} / 1$. It is not yet officially approved in Finland.

In the results the yield is presented as dried to the $15 \%$ moisture content. The weed counting shows the number of all weeds per $\mathrm{m}^{2}$, and the dry weight of weeds is given as $\mathrm{g} / \mathrm{m}^{2}$. The number of mayweeds per $\mathrm{m}^{2}$ is given also separately.

The heat summation during the months of May-September (daily temperature degrees above $+\mathbf{5}$ summed up), and the precipitation in $\mathbf{m m}$ also in monthly sums, were recorded at the weather station of Maasoja situated seven $\mathrm{km}$ from the Kotkaniemi farm. They are shown in Fig. 1. The dates of harvesting are also given in Fig. 1 both as real dates and as plotted to the monthly heat summation.

\section{Results}

The yield increase and the moisture decrease are presented in Fig. 2 for each year. The yield increase varied $16-1230 \mathrm{~kg} / \mathrm{ha}$, the average being 439 $\mathrm{kg} / \mathrm{ha}$ when compared to the average yield of unspraeyd plots at a level of 3265
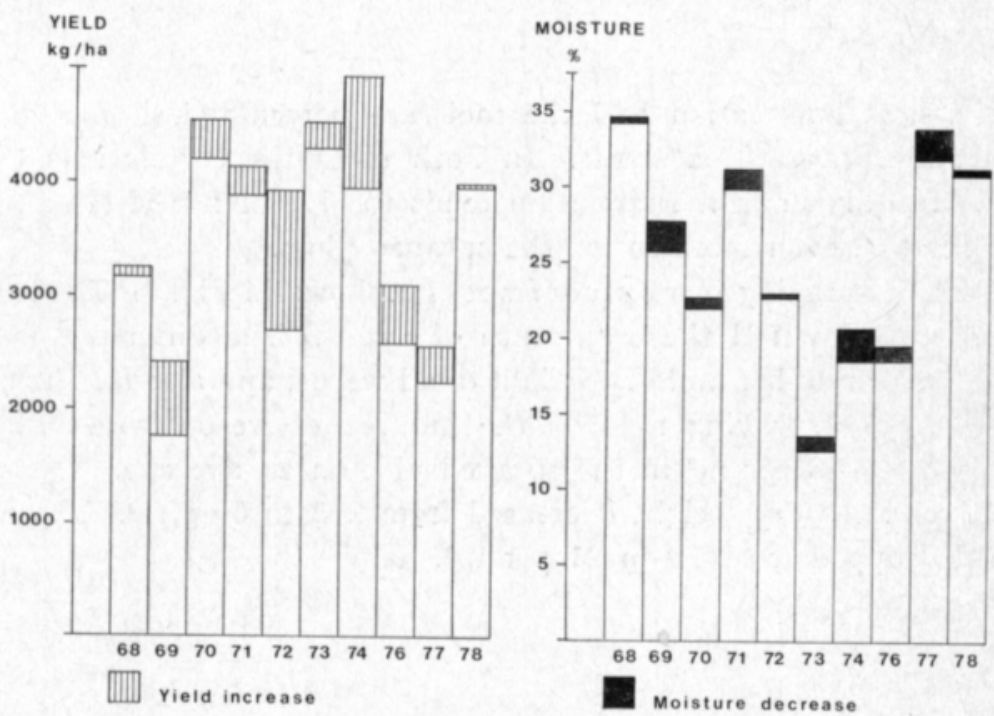

Fig. 2. Yield increase and moisture decrease due to spraying in 1968-1978.

$\mathrm{kg} / \mathrm{ha}$. The moisture content at the harvest varied $13.6-34.6 \%$ in the unsprayed, and $12.7-34.4 \%$ in the sprayed plots. On an average the moisture content was $1.2 \%$ lower in the sprayed plots.

The correlations between the heat summation and the yield for unsprayed and sprayed treatments are shown in Fig. 3 together with the correlations 
YIELD KG/HA

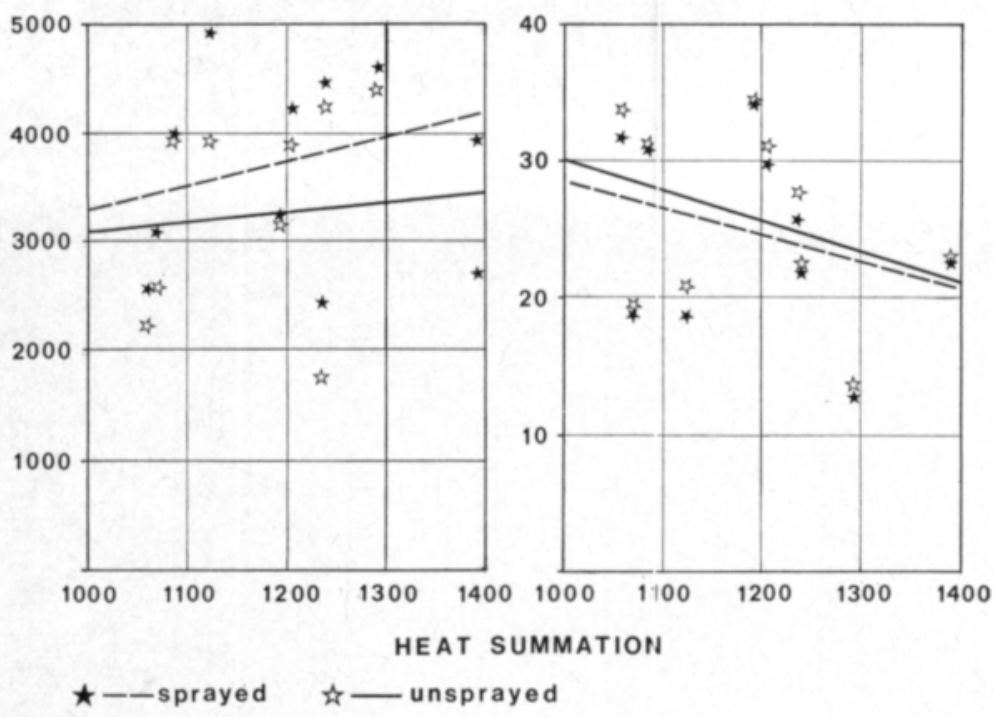

Fig. 3. Correlations between the heat summation and the yield for the unsprayed and sprayed treatments, and between the heat summation and the moisture content at the time of harvesting in 1968-1978. All the correlations are not significant.

between the heat summation and the moisture percentage similarly for the unsprayed and sprayed treatments. In both cases the correlations are not significant. The higher heat summation tends to give higher yields and lower moisture contents, even more so for the sprayed plots.

The effect of spraying in respect of weeds is shown in Fig. 4. The herbicide treatment clearly lowered the occurrence of weeds. The difference is highly significant for the number and dry weight of all weeds, and also for the number of mayweeds. The spraying reduced the number of weeds from 312 in the unsprayed plot to 48 per $\mathrm{m}^{2}$ in the sprayed plot on an average.

Respectively, the dry weight decreased frorn 263 to $69 \mathrm{~g} / \mathrm{m}^{2}$. The number of mayweed dropped from 76 to 21 per $\mathrm{m}^{2}$.

\section{Discussion}

Weeds are causing serious economic losses in cereals. According to JoHANsSoN (1978) the yearly losses due to weeds are 200 million crowns in Sweden. With the herbicidal treatments the yield increase in winter wheat in Sweden has been $250-300 \mathrm{~kg} / \mathrm{ha}$ or $6 \%$ at a yield level of $4600-5300 \mathrm{~kg} / \mathrm{ha}$ (BREITENSTEIN 1971, GUMmesson 1978). It the present relatively small material the obtained average yield increase of $439 \mathrm{~kg} / \mathrm{ha}$ or $13 \%$ at a yield level of 3265 $\mathrm{kg} / \mathrm{ha}$ is much higher. Similar results were psesented by KöYLIJÄRvI (1974) who obtained an average yield increase of $480 \mathrm{~kg} / \mathrm{ha}$ in winter wheat with early sprayings. These results from Finland may be due to the fact that weeds 

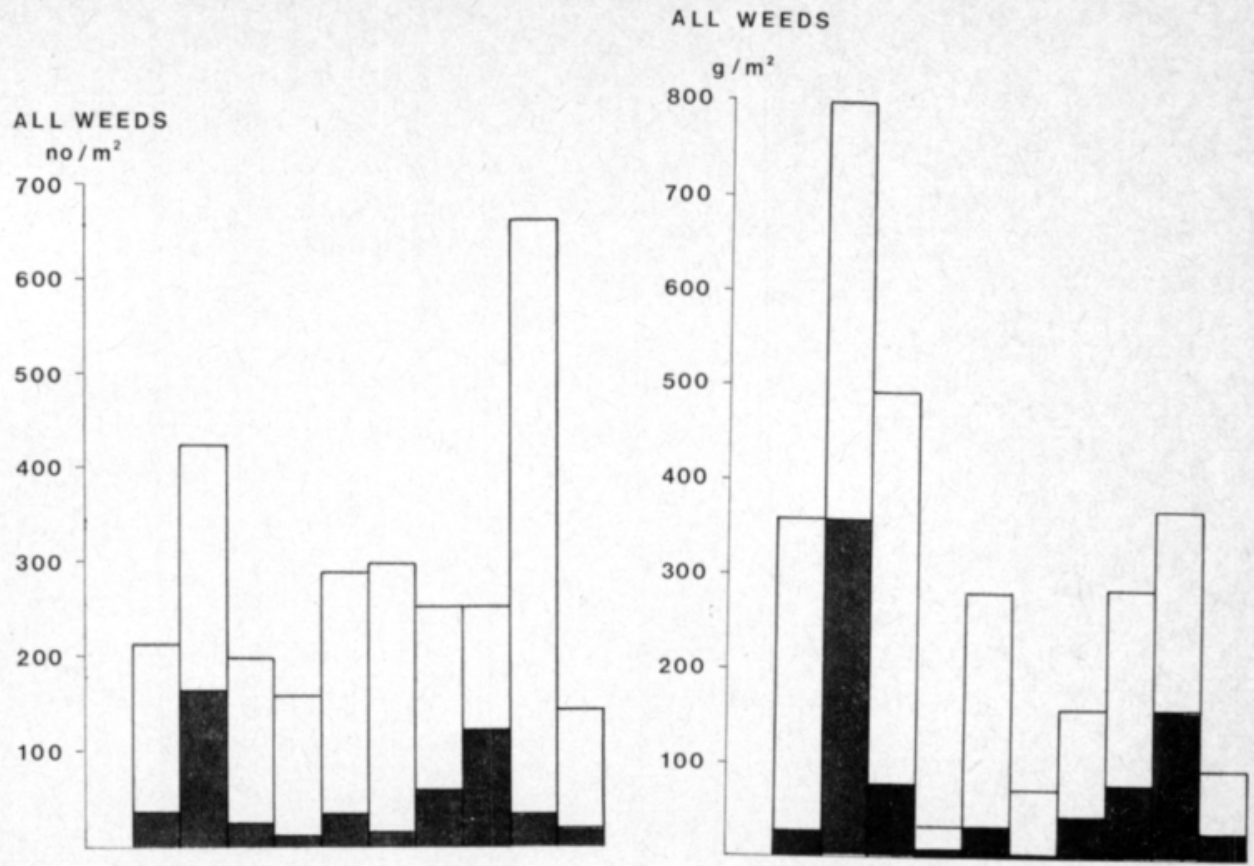

Fig. 4. Effect of spraying on the number of all weeds per $\mathrm{m}^{2}$, on the dry weight of all weeds per $\mathrm{m}^{2}$, and on the number of mayweed separately per $\mathrm{m}^{2}$. (F-values correspondingly $19.32, * *$ $9.47^{* *}$ and $\left.8.82^{* *}\right)$.

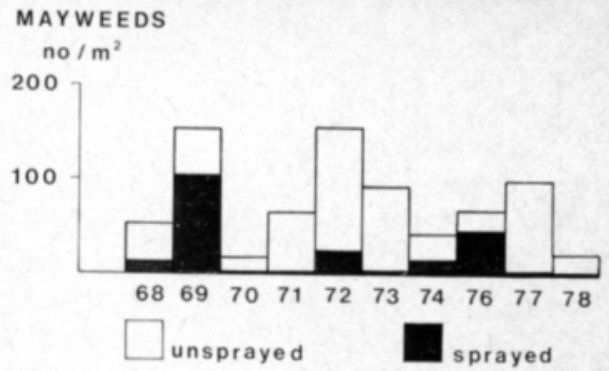

are more abundant and more harmful in Finland than in Sweden. Another explanation may lie in the lower yield level.

The Actril-type herbicide is known to be gentle to the crop and yet very effective in weed control (Robinson and Fenster 1973, Gummesson 1978). In these trials the herbicide has also given a yield increase every year, even with a rather small weed population.

It is obvious that the heat summation and the precipitation are among the major factors determining the final yield each year. When the heat summation reaches 900 already at the end of July, high yields can expected, particularly when precipitation in May and June has been sufficient. The high heat summation also promotes lower moisture content. It is interesting to note that the harvesting dates follow the heat summation much more than the calendar. The maturing of the crop occurs each year at the heat summation of $900-950$. The effect of these two weather factors on the weed population is more difficult to evaluate. Spraying has lowered the abundance of weeds every year significantly, although the degree of lowering does not necessarily correlate with the yield increase obtained. 
From the farmer's point of view the economical result due to the chemical treatment is important. This can be simply calculated on the basis of the present wheat price for the farmer which is $1 \mathrm{mk} / \mathrm{kg}$ and the estimated drying cost of $0.008 \mathrm{mk} / \% / \mathrm{kg}$. The yield increase of $439 \mathrm{~kg}$ makes $439 \mathrm{mk} / \mathrm{ha}$ and the $1.2 \%$ moisture decrease at the yield level of $3704 \mathrm{~kg}$ gives a saving in drying costs of $36 \mathrm{mk} / \mathrm{ha}$. At present the cost of $5.5 \mathrm{l}$ of Actril 4 is according to the retail price $123 \mathrm{mk} / \mathrm{ha}$. With the spraying cost of one hectare, estimated to be 30 $\mathrm{mk}$, it adds up to $153 \mathrm{mk} / \mathrm{ha}$ as the total cost of weed control. The net return for the farmer is thus $439 \mathrm{mk}+36 \mathrm{mk}-153 \mathrm{mk}=322 \mathrm{mk} / \mathrm{ha}$. With the new Actril $\mathrm{S}$ herbicide based on reduced rates of active ingredients, the cost of the herbicide will be lowered considerably which in turn will increase the profit. In addition to the direct decrease in drying, the lower moisture content due to the spraying also promotes earlier harvesting which in some years can be of primary importance. Certain economic advantages are also achieved by reducing the weed population to such a low level that the harvesting is easy, the grain yield contains only a few weed seeds and the amount of new weed seeds decreases in soil, their value is more difficult to evaluate, however.

\section{REFERENCES:}

Breitenstern, W. 1971. Sadon lisäys kevätviljoilla $300 \mathrm{~kg}$ ja $14 \%$. Rikkakasviruiskutukset kannattavia. Leipä Leveämmäksi 3: 24-25.

ERviö, L-R. 1978. The effect of the sowing date and density of winter cereals on weeds. Ann. Agric. Fenn. 17: 18-22.

Gummesson, G. 1978. Ogräsbekämpning i höstvete. 19:e svenska ogräskonferensen, Uppsala 1-3 februari 1978, p. 7-33.

JoHansson. W. 1978. Ekonomisk värdering av förluster orsakade av växtskadegörare i jordbruket. Växtskydds- och ogräskonferenserna 1978. Växtskyddsrapporter, Jordbruk 3: 7-18.

KöYLIJÄRVI, J. 1964. Syysviljojen ruiskutusaika. Kasvinsuojeluseuran yhdeksäs rikkakasvipäivä, p. 4-5.

Mukula, J. 1963. Rikkaruohot ja niiden torjunta. 140 p. Helsinki.

Robinson, L. R. \& Fenster, C. R. 1973. Winter wheat response to herbicides applied postemergence. Agr. J. 65: 749-751.

Titttanen, K. \& Blomqvist, H. 1978. Sales of pesticicles in Finland 1977. Kemia-Kemi 10: $481-483$.

Ms received July 17,1979 


\title{
Kemiallinen rikkakasvintorjunta syysvehnässä: teho ja taloudellisuus
}

\author{
JuHani Uoti ja Tuomo Juvankoski
}

Kemira Oy, PL 330, 00101 Helsinki 10

Syysvehnän kemiallisen rikkakasvintorjunnan tehoa ja kannattavuutta selvitettiin vv. 1968-1978 Kotkaniemen koetilalla Vihdissä ja lähiseudun viljelijöiden pelloilla järjestetyissä kenttäkokeissa.

Kokeita oli yhteensä 22. Vuosina $1968-69$ oli vain yksi koe, kun taas muina vuosina niitä oli 2-4 eri paikoilla. Vuonna 1975 kokeita ei sopivan koepaikan puuttuessa voitu perustaa. Kokeet ruiskutettiin keväisin käyttämällä kannettavaa propaaniruiskua. Rikkakasveista tehtiin havainnot sekä laskemalla eri lajien kappalemäärät ruiskutuksen jälkeen että punnitsemalla ilmakuivan rikkakasvimassan paino korjuuvaiheessa. Korjuu suoritettiin joko normaalilla leikkuupuimurilla tai Hege-koepuimurilla. Ruutukoko oli $4 \times 20 \mathrm{~m}$ tai viime vuosina $2,5 \times$ $10 \mathrm{~m}$. Kerranteita oli neljä. Rikkakasvihävitteenä käytettiin Actril 4-valmistetta 5,5 1/ha tai viime vuosina Actril S -valmistetta 4,0 1/ha.

Kaikkien kokeiden keskisadoksi ruiskutetuilla ruuduilla saatiin $3704 \mathrm{~kg} / \mathrm{ha}$, joka oli 439 $\mathrm{kg} / \mathrm{ha}$ enemmän kuin ruiskuttamattomilla ruuduilla. Viljan kosteus korjuuvaiheessa vaihteli ruiskutetuilla ruuduilla eri vuosina $12,7-34,4 \%$. Kosteus oli ruiskuttamattomien ruutujen satoon verrattuna säännöllisesti alhaisempi, keskimäärin $1,2 \%$-yksikköä.

Vertailtaessa eri vuosien lämpösummia voitiin todeta sadon muodostuneen ruiskutuksesta riippumatta sitä korkeammaksi, mitä korkeampi oli lämpösumma. Vastaavasti korkea lämpōsumma aiheutti puintikosteuden alenemisen. Lämpösumma vaikutti myös ratkaisevasti korjuukypsyyteen. Syysvehnän korjuu tapahtui lämpösumman saavuttaessa $900-950$ tason riippumatta kalenterista.

Ruiskutuksen vaikutus rikkakasvien vähenemiseen oli tilastollisesti erittäin merkitsevä. Keskimäärin rikkojen kappalemäärä väheni 312:sta 48:aan per $\mathrm{m}^{2}$. Vastaavasti rikkojen kuivapaino aleni $263 \mathrm{~g}$ :sta 69:ään $\mathrm{g} / \mathrm{m}^{2}$. Saunakukka, jonka runsaudesta tehtiin erikseen havainnot, väheni ruiskutuksen ansiosta $76:$ sta $21: e e n \mathrm{kpl} / \mathrm{m}^{2}$.

Ruiskutuksen kannattavuutta voidaan arvioida vähentämällä käsittelyn ansiosta saadusta sadonlisåyksestä ja kuivatuskustannusten säästöstä ruiskutuskustannukset. Vehnän tuottajahinnan ollessa tällä hetkellä $1 \mathrm{mk} / \mathrm{kg} 439 \mathrm{~kg}$ :n sadonlisäys tuo viljelijälle $439 \mathrm{mk}$. Tähän lisätään $1,2 \%$ kosteuden alenemisesta aiheutuva kuivatuskustannusten säästö, joka on $36 \mathrm{mk}$, kun arvioidaan kuivatuskustannuksiksi $0,8 \mathrm{p} / \mathrm{kg}$. Actril 4 maksaa vähittäishinnalla 5,5 litran käyttömäärällä $123 \mathrm{mk}$. Ruiskutustyő voidaan omalla kalustolla arvioida maksavan $30 \mathrm{mk}$. Viljelijälle jää näiden vähennysten jälkeen nettotuloksi vielä $278 \mathrm{mk} / \mathrm{ha}$. 